ISSN 1810-3030 (Print) 2408-8684 (Online)

Journal of Bangladesh Agricultural University

Journal home page: http://baures.bau.edu.bd/jbau, www.banglajol.info/index.php/JBAU

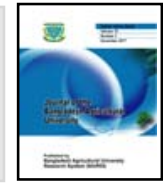

\title{
Historical trends and variability of temperature extremes in two climate vulnerable regions of Bangladesh
}

\author{
Khalid Mahmud, Susmita Saha, Tanvir Ahmad and Ummay Saima Satu
}

Department of Irrigation and Water Management, Bangladesh Agricultural University, Mymensingh-2202, Bangladesh

\section{ARTICLE INFO}

Article history:

Received: 27 February 2018

Accepted: 30 May 2018

Keywords:

Cold and warm indices,

Variability index, Mann-Kendall

test, Bangladesh

Correspondence:

Khalid Mahmud

(khalid.iwm@bau.edu.bd)

\begin{abstract}
Research on temperature extremes deserves more importance because it reacts sensitively to climate change. As elsewhere across the world, Bangladesh has already become a victim of temperature extremes. Hence, this study was conducted to assess the trends and variability of 11 temperature-related extreme indices based on daily maximum (TX) and daily minimum (TN) temperature recorded at Rajshahi and Barisal over the period 1976-2015. The indices were calculated on annual basis and their average annual and decadal trends were evaluated by non-parametric Mann-Kendall test and Sen's slope estimate. Significant $(p \leq 0.01)$ upward trend was observed in some of the hot extremes, such as SU35: number of days with $\mathrm{TX}>35^{\circ} \mathrm{C}$ and TR25: number of days with $\mathrm{TN}>25^{\circ} \mathrm{C}$, indicating that the number of days and nights with extreme hot temperature are increasing in both sites. Significant decreasing rate $(-0.308$ day/year) of SU25: number of days with $\mathrm{TX}>25^{\circ} \mathrm{C}$ and increasing rate (1.00 day/year) of SU35 demonstrate that moderate hot days are converting to extreme hot days at Rajshahi. All cold indices showed significant $(\mathrm{p} \leq 0.05)$ variations at Rajshahi implying that cold extremes are becoming severe in this area. Significant rising trend of diurnal temperature range (DTR) indicated the higher rate of increase in TX than in TN at Rajshahi. The increasing trend of all hot indices at Barisal, close to the coast, reveals more warming in hot extremes. However, no significant trends of cold indices were observed at Barisal. Significant average decadal variations of temperature indices were only observed for hot index TNx: annual maximum $\mathrm{TN}\left(0.372{ }^{\circ} \mathrm{C} /\right.$ decade $)$ and cold index $\mathrm{CD} 25$ : number of days with $\mathrm{TX}<25^{\circ} \mathrm{C}(4.70$ days/decade) at Rajshahi and hot index SU35 (5.650 days/decade) at Barisal. So, the relatively dry western region of the country is vulnerable to both hot and cold extremes, whereas coastal area is susceptible to only hot extremes.
\end{abstract}

\section{Introduction}

Global warming has already manifested changes in climate extremes as well as changes in climate averages. Changes in climate extremes deserve more attention of scientific community because they react more sensitively to climate change than mean climate (Katz and Brown, 1992). Substantial changes in the frequency of temperature extremes may occur whereas one can observe relatively small changes in the mean temperature (Mearns et al., 1984; Hansen et al., 1988).Changes in frequency, intensity, spatial extent, duration and timing of extreme temperature events have already been observed over the planet (Meehl et al., 2007). All these are resulting in unprecedented impacts on different parts of life.

Agriculture is very responsive to precipitation and temperature extremes. The effects of extreme temperature on mortality, comfort, ecology, agriculture and hydrology are already evident (Ciais et al., 2005; Patz et al., 2005). Higher temperature adversely affects plant growth, pollination and reproductive processes (Klein Tank et al., 2006; Sacks and Kucharik, 2011). A short period of abnormally high or low temperatures can have a significant harmful effect on crop growth and final yield (Mearns et al., 1984). As elsewhere across the world, most imminent impacts of climate change in Bangladesh are mainly attributed to the higher daily temperature and temperature-related extreme events (Shahid et al., 2016). The effects of temperature extremes on agriculture (Sikder et al., 2014) and other sectors (Shahid et al., 2016) have been observed in the country. The agricultural sector is most likely to face significant yield reduction in future due to temperature variability (Islam et al., 2011). Substantial effects will be on rice production (MoEF, 2005; Yamin et al., 2005). The overall rice production in Bangladesh is predicted to decrease by an average of $7.4 \%$ every year over the period of 2005-2050 (Sarker et al., 2012) due to variation in temperature extremes. substantial efforts have been made to estimate not only changes in mean temperature series, but also changes in the frequency, intensity and duration of extreme temperature events (Easterling et al., 2000; Jones et al., 2001; Moberg and Jones, 2005; Alexander et al., 2006). These studies have analyzed temperature extremes at different spatial scales, ranging from the regional to the global. Overall, a global significant decrease in cold temperature extremes and an increase in the frequency and intensity of hot extremes have been noted (Alexander et al., 2006; Wu et al., 2017). South Asian countries have been observing an increase in occurrence of extreme climate events in recent decades (Ghosh et al., 2016). However, the characteristics of climate extremes are still poorly understood at regional scale. Therefore, monitoring the actual changes in climate extremes is needed for many regions, particularly in Africa, South America and parts of Asia (Alexander et al., 2006).
Considering the consequences of temperature extremes, 
Several attempts have been made to detect the climate change and climate extremes in Bangladesh. Over the past few decades, a warmer winter with a prominent increase in the minimum temperature and more hot summer were experienced by the country (Nishat and Mukherjee, 2013). General increasing trends of monthly average temperature both in winter and summer seasons and yearly average temperature were observed at different agro-ecological zones (Mia, 2003). The increasing trend was observed for monthly maximum temperature, whereas the monthly minimum temperature showed both decreasing and increasing trends (Islam et al., 2004). Similarly, yearly average maximum and minimum temperatures recorded at Rajshahi, Barisal and Mymensingh stations showed an increasing trend over a period spanning from 1961 to 2009; however, the incremental rate was higher in case of minimum temperature (Rahman et al., 2017). An overall increasing trend for annual average temperature and decreasing trends for the annual highest maximum and lowest minimum temperatures (Nasher and Uddin, 2013) were found for Rajshahi station. All these studies have analyzed the trends of average temperature and temperature extremes, but the later only considered monthly and yearly maximum and minimum values as extremes. However, to better characterize the temperature extremes, the Expert Team on Climate Change Detection and Indices (ETCCDI) has defined 16 temperature extreme indices, which are widely used in climate change related studies in different parts of the world (Zhang et al., 2011). International community has agreed to the ETCCDI indices aiming to monitor changes in extremes and to augment studies on climate extremes as these are statistically robust, and cover a wide range of climates (Keggenhoff et al., 2014). The indices also have potential to obtain a broad and more reliable scenario of temperature behavior in the study area (El Kenawy et al., 2011). Researchers from different regions or countries can calculate the indices the same way such that the results are comparable with analysis conducted elsewhere in the world and can fit perfectly into the global picture (Guan et al., 2015). Very few studies in Bangladesh have so far incorporated some of these indices. Hasan et al. (2013) computed and analyzed six extreme temperature indices to focus on their seasonal changes by using finer resolution climatic change projections. Shahid et al. (2016) also analyzed the trends of six threshold temperature indices and their impacts on different sectors of Bangladesh. However, there is still enough scope to better characterize the temperature-related climate extremes in Bangladesh by incorporating a wide variety of ETCCDI extreme temperature indices. Moreover, it is necessary to compare country's climate change with global climate change as well as to assess how global warming might affect the country's future climate. Therefore, this study aims to calculate ETCCDI defined extreme temperature indices and analyze their average annual and decadal trends to check the reality of climate change in two climate-vulnerable (drought prone and coastal) areas of Bangladesh.

\section{Materials and Methods}

\section{Study area}

Barisal and Rajshahi were selected as the study area (Figure 1). These regions, respectively, represent the coastal and dry ecosystems, which are sensitive to climate change (Rahman et al., 2017). Barisal is a coastal district of Bangladesh having a tropical monsoon-type climate, hot and rainy summer and dry winter. This area is subjected to cyclones originating over the Bay of Bengal. Mean annual maximum and minimum temperatures of Barisal are $35.1^{\circ} \mathrm{C}$ and $12.1^{\circ} \mathrm{C}$, respectively. Annual average rainfall is about $1955 \mathrm{~mm}$. Rajshahi, the relatively dry region of the country, is drought prone and often impacted by the late arrival or early withdrawal of the monsoon. The area is characterized with rainfall, generally below $1500 \mathrm{~mm}$, summer humidity less than $50 \%$, and summer maximum temperature over $35^{\circ} \mathrm{C}$ (Banglapedia, 2006). The average elevation of Rajshahi and Barisal is $16.8 \mathrm{~m}$ and $2.1 \mathrm{~m}$, respectively.

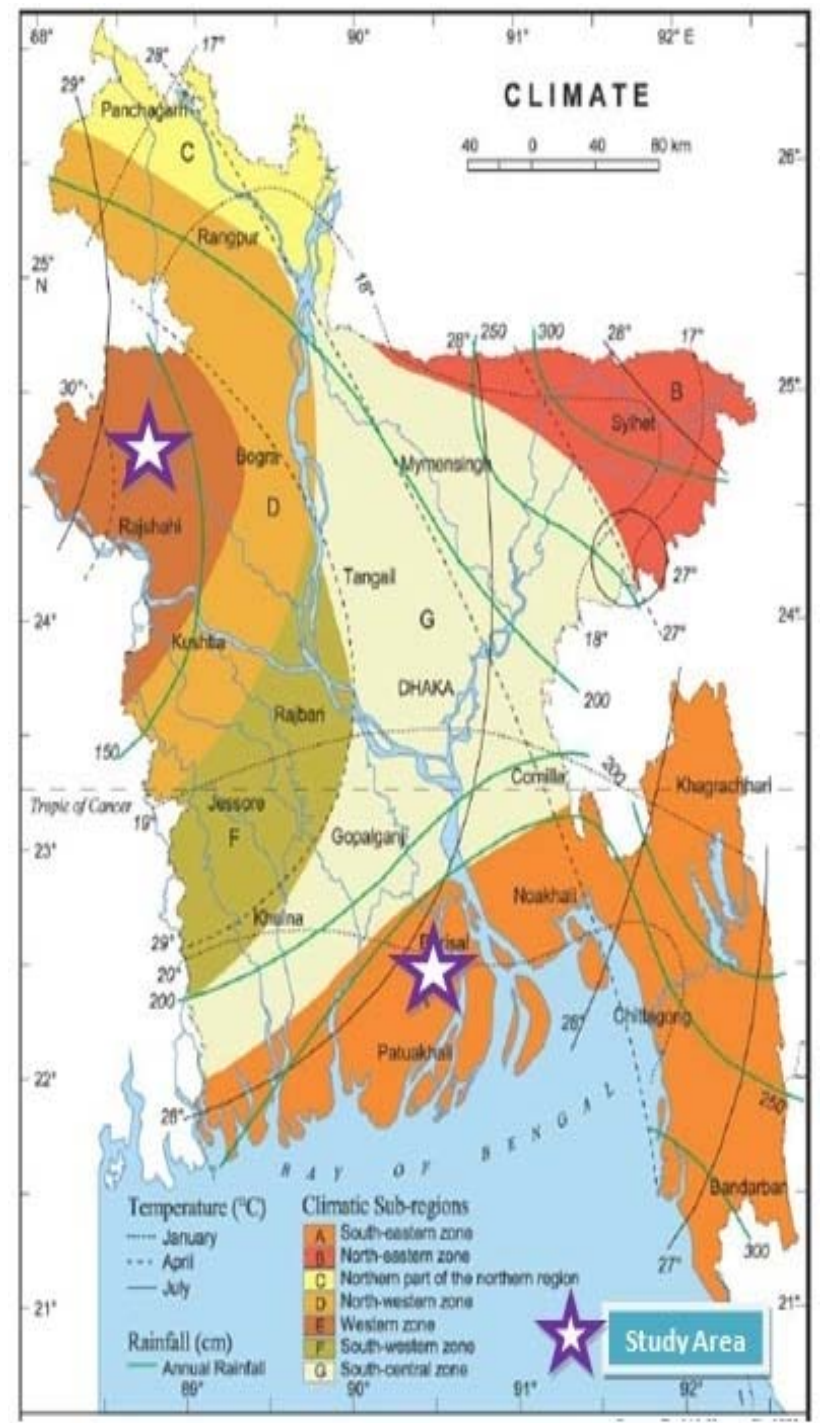

Fig 1. Locations of study areas in Bangladesh [adapted from Banglapedia (2014)]. 
Data collection and processing

Daily values of the maximum and minimum temperatures recorded at Rajshahi and Barisal meteorological stations were collected from Bangladesh Meteorological Department (BMD).There were some missing data in the collected temperature data series. The study was restricted to 40-year period of 1976-2015 to ensure the least number of missing data in temperature time series. Several data were still missing that were estimated by using nearby values. Any single missing data for a particular day in the time series was estimated by averaging the values of the previous and the following 3 days' data, whereas a series of consecutive missing values were estimated by averaging the data values of that date in the previous and the following 3 years' data (Mahmud, 2012).The collected data were subjected to several quality control checks to identify erroneous data resulting from archiving, transcription ordigitizing processes (e.g. Tmin $\geq \operatorname{Tmax}$, temperature values less than $2^{\circ} \mathrm{C}$ ). Finally, a set of 11

Table 1. Definition of extreme temperature indices

\begin{tabular}{|c|c|c|c|c|}
\hline & Index & Description & Definition & Units \\
\hline \multirow{6}{*}{ 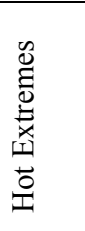 } & $\mathrm{TXx}^{\mathrm{a}}$ & Maximum TX ${ }^{\mathrm{c}}$ (Warmest TX) & Annual maximum value of TX & ${ }^{\circ} \mathrm{C}$ \\
\hline & $\mathrm{TNx}^{\mathrm{a}}$ & Maximum TN ${ }^{\mathrm{d}}$ (Warmest TX) & Annual maximum value of TN & ${ }^{\circ} \mathrm{C}$ \\
\hline & $\mathrm{SU} 25^{\mathrm{a}}$ & Summer days (Hot days) & Annual count of days where $\mathrm{TX}>25^{\circ} \mathrm{C}$ & days \\
\hline & $\mathrm{SU} 35^{\mathrm{b}}$ & Summer days (Extreme hot days) & Annual count of days where $\mathrm{TX}>35^{\circ} \mathrm{C}$ & days \\
\hline & TR20 $0^{\mathrm{a}}$ & Tropical nights (Hot nights) & Annual count of days where $\mathrm{TN}>20^{\circ} \mathrm{C}$ & days \\
\hline & $\mathrm{TR} 25^{\mathrm{b}}$ & Tropical nights (Extreme hot nights) & Annual count of days where $\mathrm{TN}>25^{\circ} \mathrm{C}$ & days \\
\hline \multirow{4}{*}{ 흥 } & $\mathrm{TXn}^{\mathrm{a}}$ & Minimum TX (Coldest TX) & Annual minimum value of TX & ${ }^{\circ} \mathrm{C}$ \\
\hline & $\mathrm{TNn}^{\mathrm{a}}$ & Minimum TN (Coldest TN) & Annual minimum value of $\mathrm{TN}$ & ${ }^{\circ} \mathrm{C}$ \\
\hline & $\mathrm{CD} 25^{\mathrm{b}}$ & Cold days & Annual count of days where $\mathrm{TX}<25^{\circ} \mathrm{C}$ & days \\
\hline & $\mathrm{CN} 10^{\mathrm{b}}$ & Cold nights & Annual count of days where $\mathrm{TN}<10^{\circ} \mathrm{C}$ & days \\
\hline 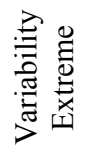 & $\mathrm{DTR}^{\mathrm{a}}$ & Diurnal temperature range & Annual mean difference between TX and TN & ${ }^{\circ} \mathrm{C}$ \\
\hline
\end{tabular}

${ }^{\mathrm{a}}$ ETCCDI defined index; ${ }^{\mathrm{b}}$ Authors' defined index; ${ }^{\mathrm{c}} \mathrm{TX}=$ Daily maximum temperature; ${ }^{\mathrm{d}} \mathrm{TN}=$ Daily minimum temperature
Trend analysis was done by using MAKESENS trend model. MAKESENS performs two types of statistical analyses. First, the presence of a monotonic increasing or decreasing trend is tested with the nonparametric Mann-Kendall test (Kendall, 1975) and, secondly, the slope of a linear trend is estimated with the nonparametric Sen's method (Gilbert, 1987). The MannKendall statistic is a rank-based nonparametric test, which is advantageous compared to parametric tests because it is robust to outliers and does not assume an underlying probability distribution of the data series. That is why this statistic has been widely used in climatological and hydrological applications (Choi et al., 2009). The Sen's method uses a linear model to estimate the slope of the trend and the variance of the residuals remains constant in time. Missing values are allowed, and the data need not conform to any distribution. Details of the Mann-Kendall test and Sen's Slope

\section{Methods for trend analysis}

extreme temperature indices were calculated on annual basis using Microsoft Excel spreadsheets.

\section{Definition of extreme temperature indices}

The Expert Team on Climate Change Detection and Indices, ETCCDI, has recommended a suite of 16 temperature indices that cover many relevant aspects of temperature extremes (Zhang et al., 2011, http://cccma.seos.uvic.ca/ETCCDI).These indices have been utilized often to research temperature extremes throughout the last several years and in many countries (Klein Tank et al., 2006; Li et al., 2012; Guan et al., 2015). These indices reflect different aspects in climate extremes, e.g., frequency, intensity and duration. Among the 16 ETCCDI-defined temperature indices, 7 indices (TXx, TNx, TXn, TNn, SU25, TR20 and DTR) were used for this study. In addition, based on the nature of meteorological data of Bangladesh, the authors defined 4 other threshold temperature indices, which are: SU35, TR25, CD25 and CN10. All these indices are described in the Table 1 . estimation along with their theory of statistics are found in the MAKESENS manual (Salmi et al., 2002).

\section{Data analysis}

Historical trends along with statistical significance of 11 temperature indices were calculated by using MAKESENS model in two steps. In step 1, 40-year annual time series of all temperature indices were entered into annual data worksheet of the model. The model was then run to calculate trend statistics, test $Z$ (n $=40$ ), and significance level of each index. In step 2, the inter-decadal change in the temperature indices was estimated. For that, 10-year averages for each extreme temperature index were calculated from their annual series. Hence, 4 consecutive decadal average values (past to recent) for each index were found and entered into MAKESENS annual data worksheet considering them as continuous annual data. The model was again run for test $S(n=4)$ and statistical significance was calculated. 


\section{Results and Discussion}

\section{Inter-annual variations}

Hot extremes: General upward/increasing trends in most of the hot extremes such as TNx (annual maximum $\mathrm{TN}$ ), SU35 (number of days with $\mathrm{TX}>35^{\circ} \mathrm{C}$ ), TR20 (number of days with $\mathrm{TN}>20^{\circ} \mathrm{C}$ ), and TR25(number of days with $\mathrm{TN}>25^{\circ} \mathrm{C}$ ) were observed for both Rajshahi and Barisal areas (Table 2). Two hot extremes, TXx (annual maximum TX) and SU 25 (number of days with $\mathrm{TX}>25^{\circ} \mathrm{C}$ ), changed differently at the two study sites: upward trend at Barisal and downward trend at Rajshahi. However, both SU35 and TR25 showed highly significant $(\mathrm{p} \leq 0.01)$ upward trends at both sites at a rate of $1.00 \mathrm{day} /$ year and $0.762 \mathrm{day} /$ year, respectively at Rajshahi (Table 2, Fig 2), and 0.50 day/year and 1.435 day/year, respectively at Barisal (Table 2, Fig 3). The results indicate that extreme hot days and extreme hot nights were increasing in both areas. The increasing number of hot nights at Rajshahi was in line with the findings of Shahid et al. (2016) and Brammer (2016); however, the increasing number of hot days was only consistent with Shahid et al. (2016). The index TR20 was found to increase at both areas. But, the significant average annual rate of increase ( 0.276 day/year) was found at Barisal only (Fig 3). The trend of SU25 was inconsistent with the changes of SU35 at Rajshahi. Though SU25 decreased at a rate of 0.308 day/year, a high increasing rate of SU35 (1.00 day/year) was observed, indicating that moderate hot days are converting to extreme hot days at Rajshahi (Table 2). Such change is more confined to summer as the city experienced some of the hottest days with a temperature of about $42^{\circ} \mathrm{C}$ or even more in this season (Shahid et al., 2016).This result is also consistent with the findings of Dastagir (2015) who found that warm days were increasing in the northern Bangladesh during the period of 1970-2009. At Barisal, only SU35 increased significantly $(\alpha \leq 0.001)$ (Table 2 , Fig 3$)$. In general, all the hot extreme indices revealed a general increasing trend at Barisal indicating that the area is becoming warmer day by day. This result is in support with the findings of more warming in hot extremes close to the coasts (EI Kenawy et al., 2011). Nonetheless, the result comes in contrast to the other studies documenting less warming near the coasts compared to continental areas (IPCC, 2007). The general upward trends of hot extremes at both study areas are also consistent with the results obtained in other global temperature studies (Alexander et al., 2006) as well as regional studies (Zhai and Pan, 2003; Guan et al., 2015).

Table 2. Inter-annual variations of temperature extremes

\begin{tabular}{|c|c|c|c|c|c|}
\hline & \multirow[t]{2}{*}{ Index } & \multicolumn{2}{|c|}{ Rajshahi Station } & \multicolumn{2}{|c|}{ Barisal Station } \\
\hline & & $\begin{array}{c}\text { Mann-Kendall } \\
\text { Test Z }\end{array}$ & $\begin{array}{c}\text { Sen's slope } \\
\left({ }^{\circ} \mathrm{C} \text { or days/year }\right)\end{array}$ & $\begin{array}{c}\text { Mann-Kendall } \\
\text { Test Z } \\
\end{array}$ & $\begin{array}{c}\text { Sen's slope } \\
\left({ }^{\circ} \mathrm{C} \text { or days/year }\right)\end{array}$ \\
\hline \multirow{6}{*}{ 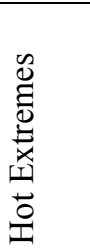 } & TXx & -0.4 & -0.012 & 1.27 & 0.020 \\
\hline & $\mathrm{TNx}$ & 1.22 & 0.013 & 1.37 & 0.114 \\
\hline & SU25 & -2.23 & $-0.308 *$ & 0.48 & 0.044 \\
\hline & SU35 & 3.24 & $1.00 * *$ & 3.30 & $0.50 * * *$ \\
\hline & TR20 & 0.83 & 0.167 & 1.90 & $0.276^{+}$ \\
\hline & TR25 & 3.86 & $0.762 * * *$ & 3.37 & $1.435 * * *$ \\
\hline \multirow{4}{*}{ 흥 } & TXn & -3.34 & $-0.12 * * *$ & -1.91 & $-0.067^{+}$ \\
\hline & $\mathrm{TNn}$ & -2.71 & $-0.044^{*}$ & 0.55 & 0.004 \\
\hline & CD25 & 2.94 & $0.506 * *$ & 0.51 & 0.067 \\
\hline & CN10 & 2.45 & $0.333^{*}$ & -0.06 & 0 \\
\hline 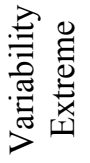 & DTR & 1.71 & $0.013^{+}$ & 4 & 0 \\
\hline
\end{tabular}

$\mathrm{NB}:^{+}=0.1$ level of significance, $*=0.05$ level of significance, $* *=0.01$ level of significance, $* * *=0.001$ level of significance; negative sign indicates decreasing trends 
- Data -Sen's estimate
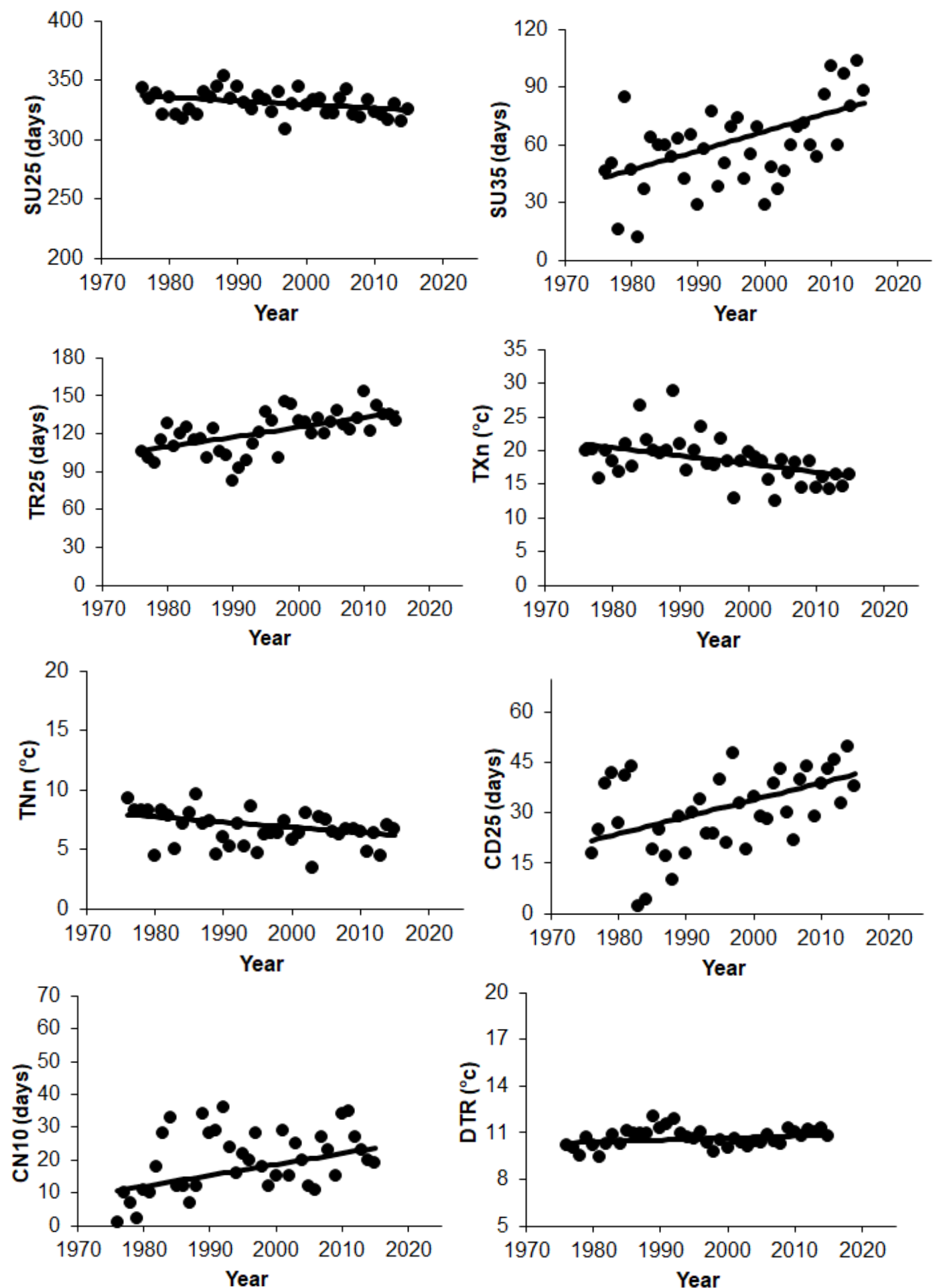

Fig. 2. Average annual trends of hot indices, i.e. SU25 (days with daily maximum temperature (TX) $>25{ }^{\circ} \mathrm{C}$ ), SU35 (days with TX $>35^{\circ} \mathrm{C}$ ), TR25 (days with daily minimum temperature (TN) $>25^{\circ} \mathrm{C}$ ); cold indices i.e. TXn (annual minimum TX), TNn (annual minimum TN), CD25 (days with $\mathrm{TX}<25{ }^{\circ} \mathrm{C}$ ), $\mathrm{CN} 10$ (days with $\mathrm{TN}<10{ }^{\circ} \mathrm{C}$ ) and variability index DTR (diurnal temperature range) at Rajshahi 

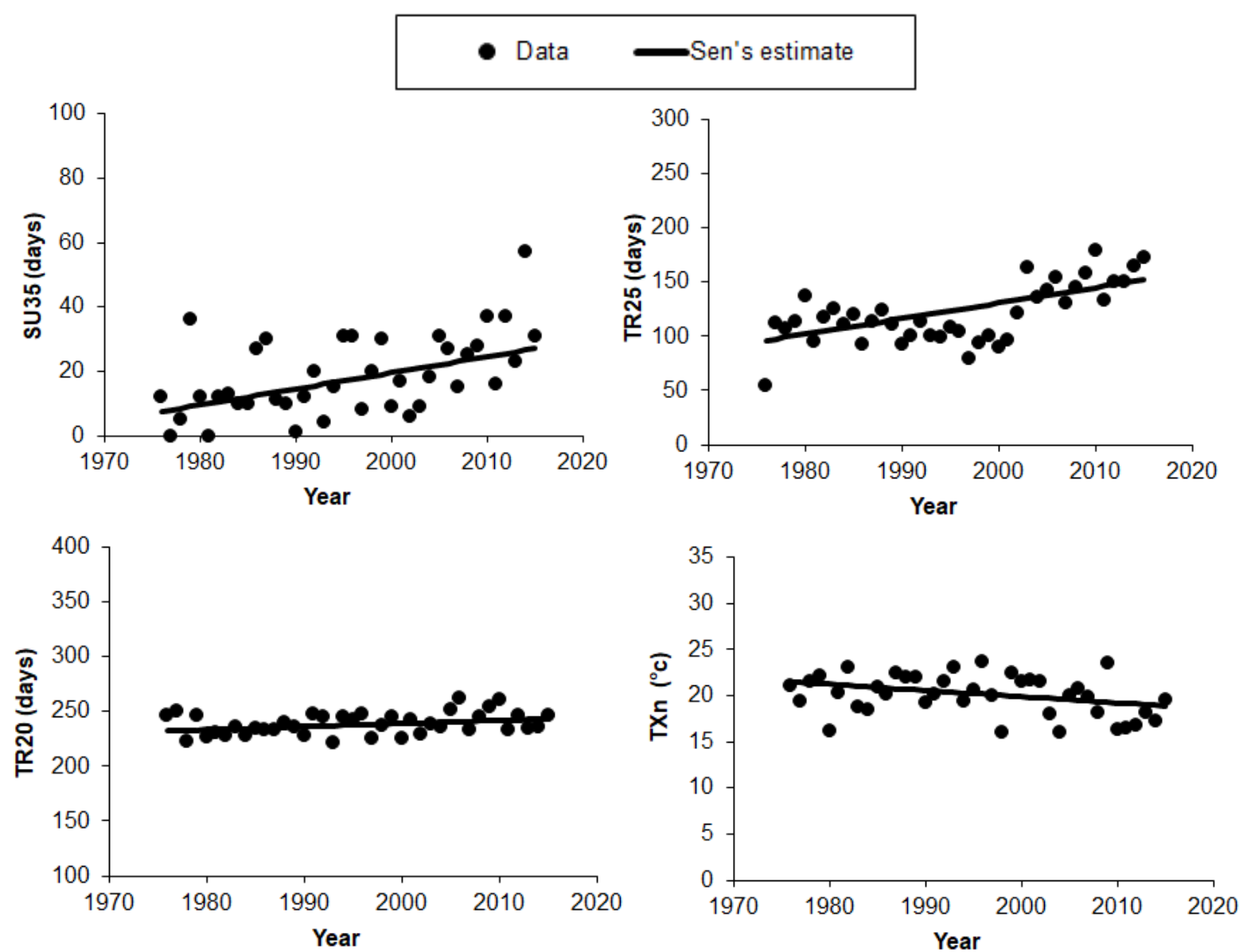

Fig. 3. Average annual trends of hot indices, i.e. SU35 (days with daily maximum temperature (TX) $>35^{\circ} \mathrm{C}$ ), TR25 (days with daily minimum temperature $(\mathrm{TN})>25^{\circ} \mathrm{C}$ ), TR20 (days with $\mathrm{TN}>20^{\circ} \mathrm{C}$ ) and cold index $\mathrm{TXn}$ (annual minimum $\mathrm{TX}$ ) at Barisal

Cold extremes: Among the cold extreme indices, TXn (annual minimum TX) showed significant downward trends at both study sites (Table 2, Figs 2 \& 3). In contrast, TNn (annual minimum TN) showed significant downward trends at Rajshahi but insignificant upward trend at Barisal (Table 2). General downward trends of these indices, except $\mathrm{TNn}$, designate that cold extremes are generally getting severe meaning that winter is getting colder. Two cold extreme indices, CD25 (number of days with $\mathrm{TX}<25^{\circ} \mathrm{C}$ ) and $\mathrm{CN} 10$ (number of days with $\mathrm{TN}<10^{\circ} \mathrm{C}$ ), showed rising trends at Rajshahi (Fig 2), signifying that number of cold days and cold nights increased over the study period at a rate of 0.506 day/year and 0.333 day/year, respectively. Such cold extremes are particularly skewed to January when the temperature falls to about $5^{\circ} \mathrm{C}$ or even less. Similar results were also found for a study period of 1958-2012 at the same place (Shahid et al., 2016). Such findings are, however, not sufficient to conclude the increasing trends of cold extremes at Rajshahi because the area also experienced with reduction in the number of cold nights (Dastagir, 2015). Increasing changing pattern of cold days $(\mathrm{CD} 25=0.067$ day/year) was found at Barisal but it was not statistically significant. In general, changes in cold extremes for both study areas are not too prominent like hot extremes. Similar findings, confirmed in other studies worldwide, showed little changes in cold extremes and lower variance in cold tail of temperature distribution (EI Kenawy et al., 2011).

Variability extreme: Variability index DTR (annual mean difference between daily maximum and minimum temperatures) of Rajshahi showed significant increasing trend $\left(0.013{ }^{\circ} \mathrm{C} /\right.$ year $)$ at $10 \%$ level of significance (Table 2, Fig 2). The change of the diurnal temperature range (DTR) is related to the asymmetric evolution of both maximum and minimum temperature. The increasing trend of DTR at Rajshahi is linked to the higher increasing rate in maximum temperature than in minimum temperature. Similar evidence was found not only at Rajshahi, but also at Chittagong and Sylhet (Shahid et al., 2016). The result, however, contradicts with several studies (Dai et al., 1997; Easterling et al., 2000), showing that the globe has experienced a general downward trend in DTR that is mainly due to the rapid increase in minimum temperatures rather than maximum temperatures. Significant increasing trend of DTR confirms that Rajshahi experienced a more warming environment during the last four decades. 
Inter-decadal variations

Inter-decadal variations of temperature extremes were almost consistent with the average inter-annual variations with few exceptions at Barisal where downward inter-decadal trends of two cold extremes, CD25 and CN10 (Table 3), were observed that contradicts with their upward average annual and no annual trend (Table 2). This is due to the inconsistent variation of decadal averages and lowest number of data values $(n=4)$ for decadal trend analysis. One hot extreme (TNx) and one cold extreme (CD25) at Rajshahi respectively showed significant upward trends of 0.372 ${ }^{\circ} \mathrm{C} /$ decade and 4.70 days/decade (Fig 4) at $10 \%$ level of significance. Similarly, one hot index, SU35 (TX > $35^{\circ} \mathrm{C}$ ), showed significant upward trend meaning that summer days significantly increased $(p<0.1)$ at a rate of 5.650 days/decade during the study period at Barisal (Fig 5). Inter-decadal variation of DTR showed insignificant increasing trends at both Rajshahi and Barisal (Table 3). Significant increasing decadal changes of warm indices at Rajshahi (TNx) and Barisal (SU35) are in line with several previous studies done in Bangladesh (Dastagir, 2015; Shahid et al., 2016) and worldwide (Guan et al., 2015; EI Kenawy et al., 2011).However, increasing trend of CD25 at Rajshahi was not in line with the previous studies, perhaps, due to use of higher threshold value $\left(25^{\circ} \mathrm{C}\right)$ compared to other studies. For instance, number of cold days $\left(\mathrm{TX}<18^{\circ} \mathrm{C}\right)$ was found to decrease at a rate of 0.08 days/decade (Shahid et al., 2016), noting that extreme cold days were converting to moderate cold days in north-western Bangladesh. Results from decadal trend analysis reconfirm that hot temperature extremes are undoubtly becoming rigorous in both study regions that will likely to have diverse impacts on different sectors of those areas. For instance, substantial effects of climate change on rice water demand, rice physiology and phenology, and soil-water balances are already evident in the northwest Bangladesh (Shahid, 2011).

Table 3. Inter-decadal variations of temperature extremes

\begin{tabular}{|c|c|c|c|c|c|}
\hline \multirow{2}{*}{ 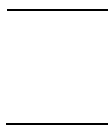 } & \multirow[t]{2}{*}{ Index } & \multicolumn{2}{|c|}{ Rajshahi Station } & \multicolumn{2}{|c|}{ Barisal Station } \\
\hline & & $\begin{array}{c}\text { Mann-Kendall } \\
\text { Test Z } \\
\end{array}$ & $\begin{array}{c}\text { Sen'sslope } \\
\left({ }^{\circ} \mathrm{C} \text { or days/decade }\right) \\
\end{array}$ & $\begin{array}{c}\text { Mann-Kendall } \\
\text { Test Z } \\
\end{array}$ & $\begin{array}{c}\text { Sen'sslope } \\
\left({ }^{\circ} \mathrm{C} \text { or days/decade }\right)\end{array}$ \\
\hline \multirow{6}{*}{ 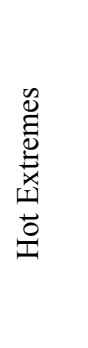 } & TXx & 2 & -0.240 & 2 & 0.126 \\
\hline & $\mathrm{TNx}$ & 6 & $0.372^{+}$ & 2 & 0.114 \\
\hline & SU25 & -4 & -3.483 & 0 & -4.167 \\
\hline & SU35 & 4 & 8.800 & 6 & $5.650^{+}$ \\
\hline & TR20 & 2 & 1.483 & 2 & 2.817 \\
\hline & TR25 & 4 & 7.050 & 4 & 11.067 \\
\hline \multirow{4}{*}{ 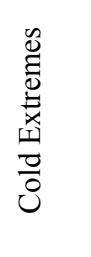 } & TXn & -4 & -1.427 & -4 & -0.732 \\
\hline & TNn & -4 & -0.430 & 4 & 0.053 \\
\hline & CD25 & 6 & $4.700^{+}$ & 0 & -0.433 \\
\hline & CN10 & 4 & 3.250 & 0 & -0.075 \\
\hline 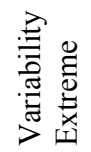 & DTR & 2 & 0.134 & 4 & 0.024 \\
\hline
\end{tabular}

$\mathrm{NB}:{ }^{+}=0.1$ level of significance, $*=0.05$ level of significance, $* *=0.01$ level of significance, $* * *=0.001$ level of significance; negative sign indicates decreasing trends 
Historical trends of daily temperature extremes
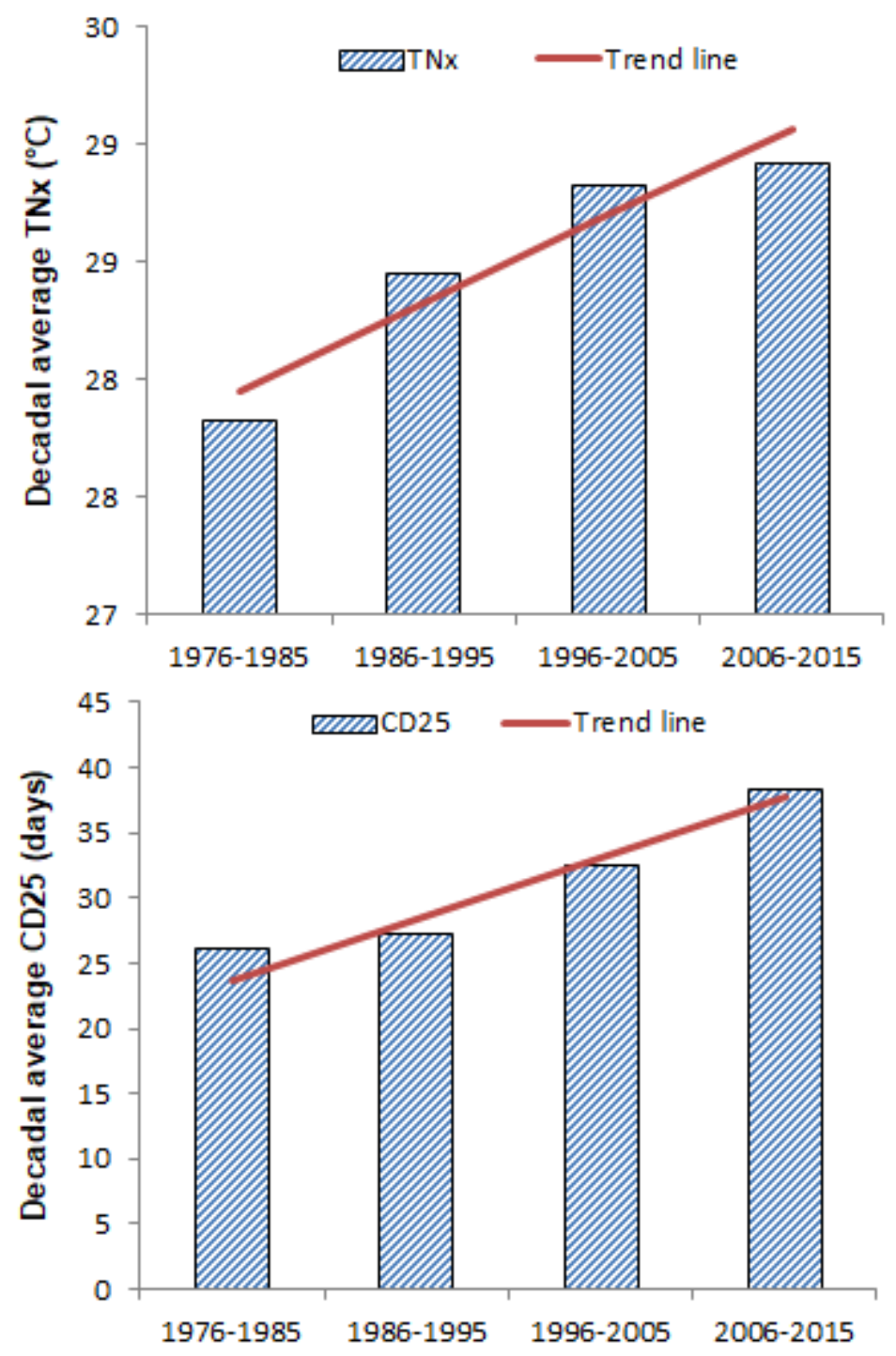

Fig 4. Decadal trends of hot index TNx (annual maximum daily minimum temperature (TN)) and cold index CD25 (days with $\mathrm{TX}<25^{\circ} \mathrm{C}$ ) at Rajshahi

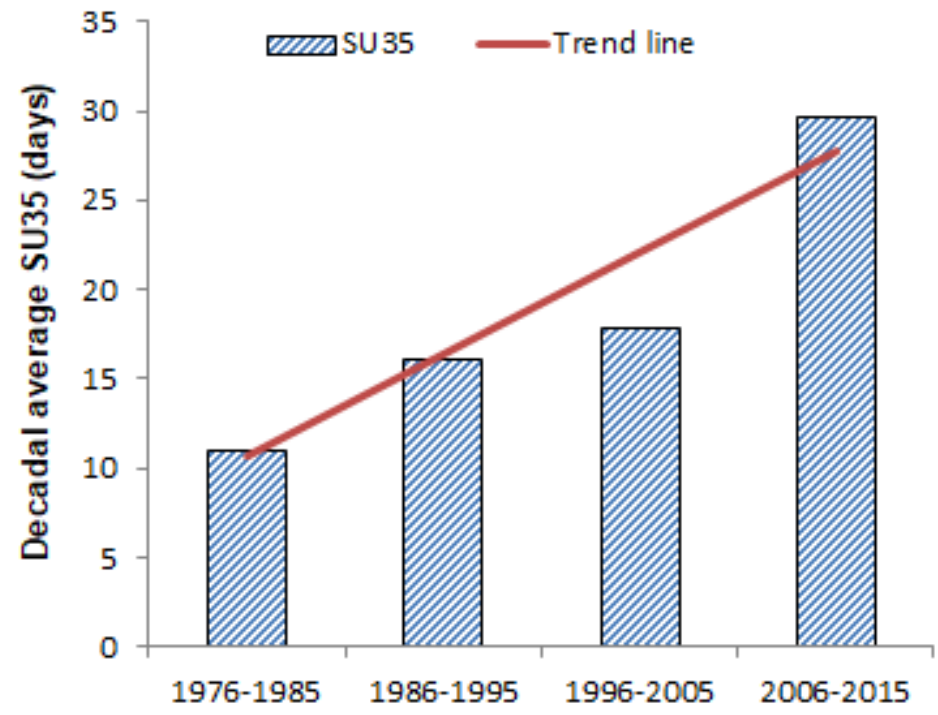

Fig 5. Decadal trend of hot index SU35 (days with daily maximum temperature $>35^{\circ} \mathrm{C}$ ) at Barisal 


\section{Conclusion}

Climate extreme is now an important research topic because the study of climate extremes is crucial to characterize the nature of climate change and its impacts. Contemplating this, trends of some temperature related hot and cold extreme indices were analyzed using daily maximum and minimum temperature recorded at two weather stations in coastal and droughtprone areas of Bangladesh. Statistically significant variations were observed in both hot and cold indices. Specifically, some of the hot indices like extreme hot days and hot nights increased significantly in both study sites. Besides, a clear evidence of converting moderate hot days into extreme hot days was noticed at Rajshahi. Among cold indices, both cold days and cold nights showed significant upward trends at Rajshahi, but no significant trend was observed at Barisal. Significant rising trend of diurnal temperature range was found at Rajshahi because the rate of increase in daily maximum temperature was higher than that in daily minimum temperature. Generally, this study provides strong evidence of the increasing trend of hot extremes in both areas. In contrast, drawing firm conclusions about the changes of cold extremes are difficult even though some cold temperature indices showed significant increasing trends at Rajshahi, the north-western part of the country. Results of this study will enhance the knowledge about recent changes in the climate and climate-related extreme events, their impacts on different sectors and possible adaptation actions. The present study used only two weather stations data, so further research is needed including data of more weather stations covering whole country. Study of precipitation related extremes is also needed for general understanding of climate extremes.

\section{Acknowledgement}

We are thankful to the Bangladesh Meteorological Department (BMD) for providing necessary data to successfully complete this research work. Authors would also like to express special thanks to Prof. Dr. M G Mostofa Amin for his help during manuscript preparation. We greatly appreciate the constructive comments by the reviewers which were mostly helpful in improving this paper.

\section{References}

Alexander, L.V., Zhang, X., Peterson, T.C., Caesan, J., Gleason, B., Klein Tank, A.M.G., Haylock, M., Collins, D., Trewin, B., Rahimzadeh, F., Tagipour, A., Rupa Kumar, K., Revadekar, J., Griffiths, G., Uincent, L., Stephenson, D. B., Burn, J., Aguilar, E., Brunet, M., Taylor, M., New, M., Zhai, P., Rusticucci, M. and Vazquez-Aguinres J.L., 2006. Global observed changes in daily climate extreme of temperature and precipitation. J. Geophys. Res., 111, D05109. http:// dk.doi.org/10.1029/2005JD006290.

Banglapedia, 2014. 'Climate', accessed on 20 February 2018, http://en.banglapedia.org/index.php?title=Climate.

Banglapedia, 2006. National Encyclopedia of Bangladesh, CD edition, Asiatic Society of Bangladesh.

Brammer, H. 2016. Floods, cyclones, drought and climate change in Bangladesh: a reality check. Int. J. of Environ. Stud., 73(6): 865-886.
Brunetti, M., Buffoni, L., Maugeri, M. and Nanni, T. 2000. Trends of minimum and maximum daily temperatures in Italy from 1865 to 1996.Theor. Appl. Climatol., 66: 49-60.

Choi, G., Collins, D., Ren, G., Trewin, B., Baldi, M., Fukuda, Y., Afzaal, M., Pianmana, T., Gomboluudev, P., Huong, P.T., Lias, N., Kwon, W.T., Boo, K.O., Cha, Y.M. and Zhou, Y. 2009. Changes in means and extreme events of temperature and precipitation in the Asia-Pacific network region, 19552007.Int. J. Climatol., 29: 1906-1925.

Ciais, P.H., Reichstein, M., Viovy, N., Granier, A., Ogee, J., Allard, V., Aubinet, M., Buchmann,N., Bemhofer, Chr., Carrara, A., Chevallier, F., De Noblet, N., Friend, A. D., Friedlingstein, P.,Grunwald, T., Heinesch, B., Keronen, P., Knohl, A., Krinner, G., Loustau, D., Manca, G., Matteucci, G., Miglietta, F., Ourcival, J.M., Papale, D., Pilegaard, K., Rambal, S., Seufert, G., Soussana, J.F., Sanz, M.J., Schulze, E.D., Vesala, T. and Valentini, R. 2005. Europewide reduction in primary productivity caused by the heat and drought in 2003. Nature, 437: 529-534.

Dai, A., Del Genio., A.D. and Fung, I.Y., 1997. Maximum and minimum temperature trends for the globe. Nature, 386: 665-667.

Dastagir, M.R., 2015. Modeling recent climate change induced extreme events in Bangladesh: A review. Weather Clim. Extremes, 7: 49-60.

Easterling, D.R., Meehl, G.A., Parmesan, C., Changnon, S.A., Karl, T.R. and Mearns, L.O., 2000. Climate extremes: observations, modeling, and impacts. Science, 289: 20682074.

EI Kenawy, A., L'opez-Morenol, J.I. and Vicente-Serrano, S.M. 2011. Recent trends in daily temperature extremes over northeastern Spain (1960-2006). Nat. Hazards Earth Syst. Sci., 11: 2583-2603.

Ghosh, S., Roy, M.K. and Biswas, S.C., 2016. Determination of the best fit probability distribution for monthly rainfall data in Bangladesh. Amer. J. Math. Statist., 6 (4): 170-174.

Gilbert, R.O., 1987. Statistical Methods for Environment Pollution Monitoring. Van Nortrana Reinhold, New York.

Guan, Y.,Zhang, X., Zheng, F. and Wang, B., 2015.Trends and variability of daily temperature extreme during 1960-2012 in the Yantze River Basin, China. Glob. Planet change., 124: 79-94.

Hasan, M.A., Islam, A.K.M.S. and Bhaskaran, B., 2013. Predicting change of future climate extremes over Bangladesh in high resolution climate change scenarios. $4^{\text {th }}$ International Conference on Water and Flood Management. Institute of Water and Flood Management, Bangladesh University of Engineering and Technology, Dhaka-1000, Bangladesh. pp. 583-590.

Hansen, J.I., Fung, A., Lacis, D., Rind, S., Lebedelt, R., Ruedy, G. and Stone, P. 1988. Global climate changes as forecast by Goddard Institute for Space Studies three dimensional model. J. Geophys. Res., 93: 9341-9364.

Horton, B., 1995.The geographical distribution of changes in maximum and minimum temperatures. Atmos. Res., 37, $101-117$.

IPCC, 2007. Summary for policymakers. In Solomon, S., D. Qin, M. Manning, Z. Chen, M. Marquis, K.B. Averyt, M. Tignor and H.L. Miller (eds). Climate Change 2007: The Physical Science Basis. Contribution of Working Group I to the Fourth Assessment Report of the Intergovernmental Panel on Climate Change. Cambridge University Press, Cambridge, United Kingdom and New York, NY, USA.

Islam, M.B., Ali, M.Y.,Amin, M. and Zaman, S.M. 2011. Climate variations: farming systems and livelihoods in the high Barindtract and coastal areas of Bangladesh, InLal, R., M.V.Z. Sivakumar, S.M.A. Faiz, A.H.M.M. Rahmanand K.R.R. Islam. Climate Change and Food Security in South Asia, part 7, 1st Edn. pp. 477-526.

Islam, A.K.M.R., Ali, M.H. and Amin, M.G.M. 2004. Long-term variability of rainfall at different agro-ecological regions of Bangladesh. J. Soc. Agric. Sci. Tech., 1(1\&2):19-24. 
Jones, P.D., Jones, R.N., Nicholls, N. and Sexton, D.H.M. 2001 Global temperature change and its uncertainties since 1861.Geophys. Res. Lett., 28: 2621-2624.

Katz, R.W. and Brown, B.G., 1992. Extreme events in a changing climate: variability is more important than averages. Clim. Change, 21: 289-302.

Keggenhoff, I., Elizbarashvili, M., Amiri-Farahani, A. and King, L., 2014. Trends in temperature and precipitation extremes over Georgia, 1971-2010. WeatherClim. Extremes, 4:7585.

Kendall, M.G., 1975. Rank Correlation Methods.4th edition, Charles Griffin, London.

Klein Tank, A.M.G., Peterson, T.C., Quadir, D.A., Dorji, S., Zou, X., Tang, H., Santhosh, K., Joshi, U.R., Jaswal, A.K., Kolli, R.K., Sikder, A., Deshpande, N.R., Revadekar, J.V., Yeleuova, K.,Vandasheva, S., Faleyeva, M., Gomboluudev, P., Budhathoki, K.P., Hussain, A., Afzaal, M., Chandrapala, L., Anvar, H., Amanmurad, D., Asanova, V.S., Jones, P.D. New, M.G. and Spektorman, T., 2006. Changes in daily temperature and precipitation extremes in central and south Asia.J. Geophys. Res., 111, D16105, doi:10.1029/ 2005JD006316.

Kruger, A.C. and Shongwe, S. 2004. Temperature trends in South Africa, 1960-2003.Int. J. Climatol., 24: 1929-1945.

Li, Z., He, Y., Wang, P., Theakstone, W.H., An, W., Wang, X., Lu, A., Zhang, W. and Cao, W.,2012. Changes of daily climate extreme in south-western China during 19612008.Glob.Planet. Change, 80-81: 255-272.

Mahmud, K., 2012. Trend analysis of some climatic parameters of three different locations in Bangladesh. Bangladesh J. Agri. Engg., 23 (1 \&2): 21-31.

Mearns, L.O., Katz, R.W. and Schneider, S.H., 1984. Extreme hightemperature events: changes in their probabilities with changes in mean temperature. J. Clim., 23: 1601-1613.

Meehl, G.A., Stocker, T.F., Collins, W.D., Friedlingstein, P., Gaye, A.T., Gregory, J.M., Kitoh, A., Knutti, R., Murphy, J.M., Noda, A. and Raper, S.C., 2007. Global climate projections.Climate Change, 349:747-845.

Mia, N.M., 2003. Variation of temperature in Bangladesh. Proccedings of SAARC seminar on climatic variability in the South Asian region and its impacts, SAARC Meterological Research Center, pp. 94-97.

Ministry of Environment and Forest (MoEF), 2009.Bangladesh Climate change Strategy Action Plan, Government of the People Republic of Bangladesh, Dhaka, Bangladesh.

Moberg, A. and Jones, P.D., 2005. Trends in indices for extremes in daily temperature and precipitation in Central and Western Europe 1901-1999.Int. J. Climatol., 25: 1173-1188.

Nasher, N.M.R. and Uddin, M.N., 2013. Maximum and minimum temperature trends and variation over northern and southern part of Bangladesh. J. Environ. Sci. \& Nat.Resour.,6(2): $83-88$
Nishat, A. and Mukherjee, N. 2013. Climate change impacts, scenario and vulnerability of Bangladesh, In R. Shaw et al. (eds), Climate Change Adaptation Actions in Bangladesh, DOI 10.1007/978-4-431-54249-0 2, (C) Springer Japan.

Patz, J.A., Campbell-Lendrum, D., Holloway, T. and Foley. J.A., 2005. Impact of regional climate on human health. Nature, 438: 310-317.

Rahman, M.A., Kang, S., Nagabhatla, N. and Macnee, R., 2017. Impacts of temperature and rainfall variation on rice productivity in major ecosystems of Bangladesh. Agric. Food Secur., 6:10-19.

Sacks, W.J. and Kucharik, C.J., 2011. Crop management and Phenology trends in the U.S. corn belt: Impacts on yields. Agric. For. Meteorol., 151: 882-894.

Salmi, T., Määttä, A., Antilla, P., Ruoho-Airola, T. and Amnell, T., 2002. Detecting trends of annual values of atmospheric pollutants by the Mann-Kendall test and Sen's slope estimates - the Excel template application MAKESENS. Finnish Meteorological Institute / Library P.O. Box 503, FIN-00101 Helsinki, Finland. pp.7.https://www.scribd.com/ document/305735720/Makesens-Manual-2002.

Sarker, M.A.R., Alam, K. and Gow, J., 2012. Exploring the relationship between climate change and rice yield in Bangladesh: An analysis of time series data. Agric. Syst.,112: 11-16.

Shahid, S., Wang, X., Harun, S.B., Shamsudin, S.B., Ismail, T. and Minhans, A., 2016. Climate variability and changes in the major cities of Bangladesh: observations, possible impacts and adaptation. Reg. Environ. Change, 16:459-471.

Shahid, S., 2011. Impact of climate change on irrigation water demand of dry season Boro rice in northwest Bangladesh. Clim. Change, 105:433-453.

Sikder, R. and Xiaoying, J., 2014. Climate change impact and agriculture of Bangladesh. J. Environ. Earth Sci., 4 (1):3540. www.iiste.org.

Wu, X., Wang, Z., Zhou, X., Lai, C. and Chen, X., 2017.Trends in temperature extremes over nine integrated agricultural regions in China, 1961-2011.Theor. Appl. Climatol., 129 (3 \& 4): 1279-1294.

Yamin, F., Rahman, A. and Huq, S., 2005. Vulnerability, adaptation and climate disasters: a conceptual overview. IDS Bull., 36 (4): $1-14$.

Zhai, P. and Pan, X., 2003.Trends in temperature extremes during 1951-1999 in China. Geophys Res Lett,30 (17): 19-31.

Zhang, X., Alexander, L., Hergerl, G.C., Jones, P., Tank, A.K., Peterson, T.C., Trewin, B. and Zwiers, F.W., 2011. Indices for monitoring changes in extremes based on daily temperature and precipitation data. WIREs Clim. Change, 2 (6): 851-870. 